\title{
CONTRASTING PERIDOTITE XENOLITH SUITES FROM THE LETSENG KIMBERLITES.: INFERENCES FOR THE LESOTHO MANTLE
}

\author{
Dawson JB' ${ }^{1}$, and Lock NP$^{2}$ \\ 1 University of Edinburgh, Edinburgh, U.K. \\ 2 Coffey Mining, Etobicoke, Canada
}

\section{INTRODUCTIONAND GENERAL GEOLOGY}

Two kimberlite pipes intrude the Triassic basalts at Letseng-la-Terai $\left(29^{\circ} 00^{\prime} \mathrm{S} 28^{\circ} 43^{\prime} \mathrm{E}\right)$ in northern Lesotho (Lock, 1980). Cropping out at $\sim 3,100 \mathrm{~m}$ a.s.1. they form the world's highest diamond mine. The emplacement of the two pipes is assumed to be pene-contemporaneous; tough there are no radiometric dates on kimberlite from either intrusion; zircon from the nearby Mothae pipe has given an age of 87.1 Ma (Davis 1977).

The two pipes are only $\sim 350 \mathrm{~m}$ apart (Figs 1 and 2), separated by Triassic basalt that occurs as abundant xenoliths in both pipes, other xenoliths being Karoo sediments; gneisses and granulites that have their analogues in the basement of southern Africa; and upper mantle peridotites (s.l). The juxtaposition of the pipes affords the opportunity to compare two peridotite xenolith suites that can reasonably be assumed to have passed up the same or closely-adjacent mantle conduit(s). In this context, Harris et al (1979) and Bowen et al.(2009) report significant differences in terms of diamond morphology and colour between the diamond populations from the two pipes.

The Main Pipe (surface area 17.2 hectares) comprises four types ofvolcanoclastic kimberlite that are petrographically-distinct due to differing types/proportions of megacrysts and xenoliths.. Overall, the intrusive relationships between these four types of kimberlite suggest a younging towards the centre of the diatreme. The Satellite Pipe (surface area 5.2 hectares) is mainly infilled by a single body of volcanoclastic kimberlite breccia which is similar to the largest and earliest unit of the Main Pipe,but there is also an area of reworked volcanoclastic kimberlite; the main kimberlite contains more sedimentary xenoliths but much rarer peridotite xenoliths than the Main Pipe.

\section{ULTRAMAFIC XENOLITHS}

Mineralogy and textures The most common ultramafic xenoliths are garnet- or chromite-lherzolites and harzburgites, but rarer types are garnet $\mathrm{Cr}$-spinel lherzolites , garnet dunites, garnet websterites, garnet pyroxenites, Al-spinel lherzolites, and barren harzburgites (i.e.containing low-Ca-Al enstatites - Hervig et al. 1980). Primary phlogopite is present in some lherzolites, whereas secondary phlogopite, generally adjacent to garnet, is present in samples that show incipient serpentinisation. Most rocktypes are found in both the Main and Satellite pipes but barren harzburgites have been recorded thus far only from the Main Pipe. Garnet lherzolites are $\sim 3 \mathrm{x}$ more abundant in the Main Pipe

The main focus of this contribution is on the garnet lherzolites that have the requisite 


\section{0 $^{\text {th }}$ International Kimberlite Conference, Bangalore - 2012}

combinations of phases (garnet, enstatite and diopside) that enable calculations of the temperatures and pressures of equilibration as determined in experimental systems.. Measured modes and maximum grain sizes are: olivine 5478 modal $\%$, up to $6 \mathrm{~mm}$; enstatite $11-41 \%, 8 \mathrm{~mm}$; red-purple garnet $3-14 \%, 5 \mathrm{~mm}$ (including the surrounding reaction coronas); and green diopside - $0.3-10.3 \%, 4 \mathrm{~mm}$. Diopside is often spatially close to garnet. A very few samples also contain rare chrome-rich spinel $(0.3 \mathrm{~mm})$. Grain sizes in deformed rocks are less than in the coarse samples varying deformation and recrystallisation has given rise to a range of textures. Undeformed rocks are referred to as being of coarse texture.. Recrystallisation of other rocks, mainly of the olivines but also of the pyroxenes, has resulted in porphyroclastic and mosaic texture (terminology of Harte, 1977); these textures occur in rocks from both pipes. The highest strain resulted in garnet and the surrounding reaction coronas being physically disrupted and strung out into finegrained chains, interspersed, with fine layers of olivine and pyroxene neoblasts, to give the laminated and disrupted (LAD) texture (Fig.5). The rocks showing recrystallisation and LAD textures are collectively referred to as "deformed". Both coarse and deformed rocks are found in both pipes, though coarse rocks are rare in the Satellite Pipe, and those with the extreme LAD-texture have been found only in the Main Pipe.

In all samples, whether coarse or deformed, the garnets show varying degrees of reaction, generally with adjacent olivine and, more rarely, with pyroxenes. The reaction coronas consist of Al-spinel and highly-aluminous ortho- and clinopyroxene, and are of variable width; round spinelpyroxene aggregates up to $5 \mathrm{~mm}$ in diameter are interpreted as reacted-out former garnet grains.

\section{GARNET LHERZOLITE WHOLE-ROCK CHEMISTRY}

The Letseng rocks, whether coarse or deformed, are low in $\mathrm{TiO}_{2}, \mathrm{Al}_{2} \mathrm{O}_{3}, \mathrm{FeO}$ and $\mathrm{CaO}$., and are depleted compared with reference analyses for fertile mantle and, on a more local scale, deformed "fertile" garnet lherzolites from Thaba Putsoa .With reference to Mg\# (a depletion indicator), with the exception of one high-Fe sample, the Letseng lherzolites, have a narrow range from $91.0-93.2$ though with a slight tendency for lower values in the deformed samples (Fig.1).

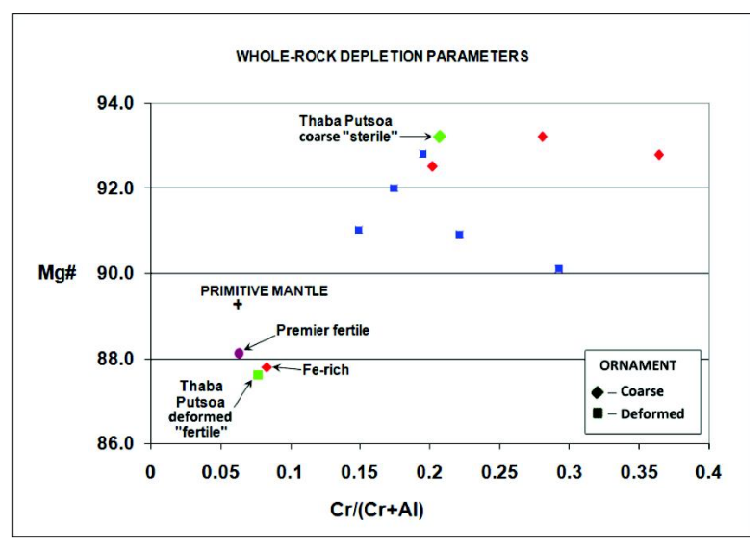

Fig. 1 Depletion data for Letšeng (red and blue ornament) and other garnet lherzolites

This compares with much greater differences between coarse sterile and sheared fertile garnet lherzolites from the Thaba Putsoa kimberlite. The $\mathrm{Cr} /(\mathrm{Cr}+\mathrm{Al}) /$ ratio (another indicator of depletion), again with the exception of the Fe-rich sample, has a narrow range from 0.033 to 0.292 , with an overlap between coarse and deformed samples. In the Letseng samples there is no correlation between degree of depletion and deformation, unlike the case of Thaba Putsoa where high deformation is linked to high "fertility" (Boyd, 1973b; Boyd and McCallister 1973). Compared with other Kaapvaal craton lherzolite suites in Cretaceous kimberlites, most Letseng lherzolites show strong similarities in terms of their bulk compositions. However, they are more refractory than garnet lherzolites in the Proterozoic Premier kimberlite the relative "fertility" of which is attributed to their having been sampled before the 
major early-Mesozoic melting/depletion event that produced the Karoo volcanics. (Danchin, 1779).

\section{PRIMARY PHASE CHEMISTRY IN GARNET LHERZOLITES}

Electron micro- probe analyses were made of the phases in twenty-four garnet lherzolites. They are supplemented by data on seven more samples from the literature; the derivation (? Main or Satellite pipe) of three of these samples (Simon et al 2003) is not known and they are referred to on Fig.2 as "Pipe Unknown"

The olivines lie mainly in the compositional range $\mathrm{Fo}_{90-94}$ with two exceptions, one from each pipe, that are more Fe-rich $\left(\mathrm{Fo}_{88-89}\right)$. There are no significant differences in the olivine compositions in coarse and deformed xenoliths, and there is a reasonable linear correlation between \% Fo and the Mg\# of the coexisting pyroxenes and garnet. Orthopyroxenes, with the exception of those in the two Fe-rich specimens (above) (Mg\# 89.8 and 90.7), show a narrow $\mathrm{Mg \#}$ range (91.6-93.7). The range in $\mathrm{CaO}(0.20-1.59$ wt.\%), reflects co-existence with clinopyroxene of varying $\mathrm{CaO}$ content and there is a tendency towards slightly higher $\mathrm{Ca}$ and $\mathrm{Fe}$ but lower $\mathrm{Mg}$ in enstatites from deformed xenoliths in both pipes . All enstatites contain appreciable $\mathrm{Al}_{2} \mathrm{O}_{3}(0.69-1.29$ wt. \%), the range indicating varying equilibrium pressures.. Clinopyroxenes are ureyitic- and chromediopsides, diopsides and sub-calcic diopsides, with a range in $\mathrm{Cr}_{2} \mathrm{O}_{3}(0.75-3.66$ wt.\%). The $\mathrm{Ca} /$ $(\mathrm{Ca}+\mathrm{Mg})$ ratio reflects the temperature-dependent solubility of enstatite in diopside and its wide range (0.338-0.487) indicates a range of equilibrium temperatures from $693-1357^{\circ} \mathrm{C}$. Subcalcic diopsides $(\mathrm{Ca} /[\mathrm{Ca}+\mathrm{Mg}]<0.40)$ are present in deformed rocks from both pipes, and intermediate values $(0.40-0.46)$ are common in the clinopyroxenes in Main Pipe samples, but not in those from the Satellite Pipe. Garnet compositions show a considerable range in both
$\mathrm{Mg \#}$ (range 78.0-86.5) and $\mathrm{Cr}$ content $\left(\mathrm{Cr}_{2} \mathrm{O}_{3}=\right.$ 2.77-11.1 wt.\%); $\mathrm{Cr}_{2} \mathrm{O}_{3}$ varies directly with $\mathrm{CaO}$ and inversely with $\mathrm{Al}_{2} \mathrm{O}_{3}$. There are no systematic chemical differences between garnets from coarse and deformed rocks in the Main Pipe samples, but those in coarse samples from the Satellite Pipe are more iron-rich than in the deformed rocks and are most similar to the single Fe-rich coarse sample from the Main Pipe. Most classify as chrome pyropes but one high $\mathrm{Ca}-\mathrm{Cr}_{2} \mathrm{O}_{3}$ garnet is a knorringitic uvarovite pyrope. None is compositionally similar to low- $\mathrm{CaO}$, high- $\mathrm{Cr}$ inclusions in diamond The spinel is magnesian chromite.

Compositions of corona minerals. The two most striking features of the pyroxenes is their high $\mathrm{Al}_{2} \mathrm{O}_{3}$ content (up to 7.8 wt. $\%$ in the enstatites and up to $8.2 \%$ in the diopsides), combined with low $\mathrm{SiO}_{2}$, similar to values found in corona pyroxenes in garnet lherzolites from Lashaine, Tanzania (Reid and Dawson, 1972). Similarly, the spinel is high in alumina.

\section{CONDITIONS OF EQUILIBRATION OF THE GARNET LHERZOLITES}

In a rigorous review of the various methods of PT calculation, Nimis and Grütter (2010) recommend the two-pyroxene thermometer of Taylor (1998) combined with the Al-in-enstatite in equilibrium with garnet (Nickel and Green, 1985) for pressure estimates; these methods of calculation are used here.

The PTs of equilibration of the primar y assemblages and their textures are shown on Figure 2., with the preferred Kalahari craton geotherm of Rudnick and Nyblade (1999). Several facts are apparent:

a) Coarse textured xenoliths have equilibrated under relatively-low PT conditions

b) The highest PT conditions are found for deformed xenoliths from both pipes; in this respect they are similar to hot, sheared, fertile xenoliths in the Thaba Putsoa kimberlite 


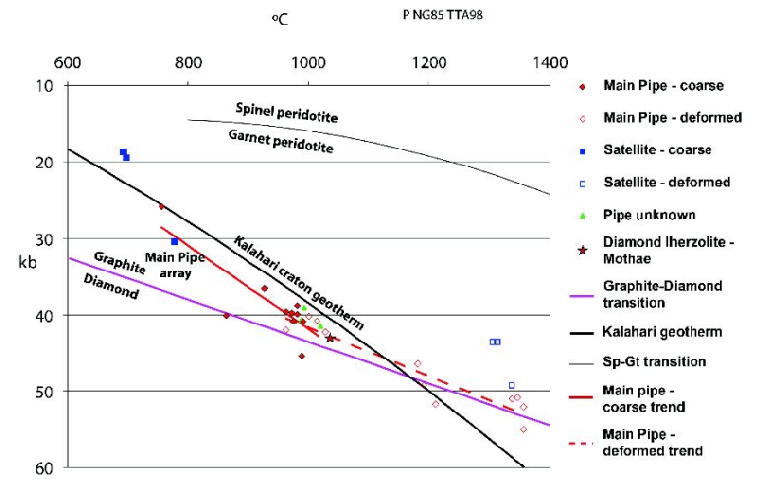

Fig.2. PT plot of Letšeng garnet lherzolite xenoliths. Mothae diamond lherzolite from Dawson and Smith (1975); spinel-garnet transition from Klemme and O’Neill (2000).

(Boyd, 1973b ). Here, however, the similarities end because, as noted above, the Letseng deformed xenoliths are depleted.

c) In the Main Pipe xenolith suite, at around $1000^{\circ} \mathrm{C}$ and $40 \mathrm{~kb}$ there is overlap between coarse-textured and deformed xenoliths, in this respect being like garnet lherzolite xenoliths from the Kimberley area (Dawson et al., 1975).

d) The Main Pipe xenoliths (with one exception), have equilibrated along a relatively-continuous linear trend whereas the PT conditions for xenoliths from the Satellite Pipe are bimodal - one group being low PT, the other at much higher PT. This might be due to uneven sampling.

e) Some Main Pipe xenoliths, both coarse and deformed, derive from an intermediate PT area apparently not sampled by the Satellite Pipe kimberlite. The "Unknown Pipe" samples of Simon et al. (2002) fall within this range

f) For a given temperature, the Main Pipe xenoliths have equilibrated at higher pressures (?greater depths) than the Satellite Pipe xenoliths

g) Compared with the preferred Kalahari Craton geotherm of Rudnick and Nyblade (1999), the Main Pipe xenolith linear array is parallel to, but cooler than, the geotherm down to a depth of $\sim 45 \mathrm{~kb}$; however, this may be due to different methods of PT calculation for the geotherm The lowest PT xenoliths from the Satellite Pipe plot close to the geotherm, but they are exceptions and their temperature estimates should be treated with caution. However, at $\mathrm{P}>45 \mathrm{~kb}$ most xenoliths from both pipes lie on the high-T side of the geotherm. This cross-over suggests an above-ambient increase in temperature, though not as high as that reported in the sheared high-PT xenoliths from the Thaba Putsoa pipe (Boyd, 1973).

h) The overall Letseng PT array extends from relatively-low to considerably higher PT conditions, in this respect resembling the lherzolites from Thaba Putsoa. This is unlike a relatively-narrow PT range found in xenolith suites in some other Lesotho kimberlites Matsokuand Pipe 200 and from the Kimberley area.

i) Most Main Pipe samples lie within the graphite stability field, though close to the transition to diamond stability.

\section{DISCUSSION}

The reaction coronas around garnets, found in both un-deformed and deformed Letseng lherzolites, show that the mantle represented by the xenoliths had moved out of the garnet- and into the spinel-stability field; this transition could have resulted from a rise in temperature, a drop in pressure, or a combination of the two (Klemme and O'Neill, 2000). Crucially, the disruption of reaction coronas in the deformed xenoliths shows that movement out of the garnet stability field preceded the deformation. Deformation fabrics are unlikely to survive in the thermal regime in the mantle before annealing so the survival of these "frozen" fabrics indicates that deformation took place immediately prior to, or coincident with, entrainment and rapid transport to the surface in the host kimberlite (Lock and Dawson, 1980). Hence the location in PT space of the xenoliths plotted on Fig 2 , as derived from the primary 
assemblages, lie at higher pressures and/or lower temperatures than those pertaining at the time of their entrainment in the host kimberlite. Currently, neither the systems investigated experimentally or modelled thermodynamically approximate to the compositions of most natural garnet lherzolites Hence, it has not been not possible to quantify the extent to which pressure drop and/or temperature increase have resulted in the formation of the reaction coronas.

We interpret the garnet reaction coronas in the Letseng lherzolites as the fresh equivalents of the metasomatically-altered kelyphite rinds surrounding garnets in lherzolites hosted in many South African Cretaceous kimberlites. This interpretation implies that movement of mantle material out of the garnet stability field has taken place on a craton-wide scale. In the Cretaceous, at the time of kimberlite intrusion, there was strong uplift of the South African continent with downwarping of the continental margin and faults of up to $3,000 \mathrm{~m}$ throwing down towards the oceanic basins (Du Toit, 1954; Dingle 1973), features that might result from upwelling of a mantle diapir. Hence a link between the continental uplift and kimberlite intrusion is implied.

\section{References}

Bowen, D.C. et al.2009. Lithos 112S, 767-774.

Boyd, F.R. 1973. Geochimica et Cosmochimica Acta 37, 2533-2546.

Boyd, F.R. and McCallister, R.H. 1976. Geophysical Research Letters 3, 509-512.

Davis, G.L. 1977.. Carnegie Inst. Washington Yearbook $76,631-654$

Dawson, J.B. et al 1975. Nature 257, 299-300.
Dawson, J.B. and Smith, J.V. 1975. Nature 254, 580581.

Dingle, E. 1973.. Palaeogeography, Palaeoclimatology, Palaeoecology 13, 203-213.

Du Toit, A.L. 1954. The geology of South Africa, Oliver and Boyd, Edinburgh.

Harris, J.W., Hawthorne, J.B. and Oosterveld, M.M. 1979. In: Boyd, F.R. and Meyer, H.O.A. (Eds), Kimberlites, diatremes and diamonds. Proceedings of the Second International Kimberlite Conference, Volume 1. Washington D.C., American Geophysical Union, 27-41.

Harte, B. 1977.. Journal of. Geology 85, 279-288.

Hervig, R.L. et al. 1980.Earth and Planetary Science Letters 50, 41-58

Klemme, S. and O'Neill, H.StC.2000. Contributions to Mineralogy and Petrology 138, 237-248

Lyubetskaya, T. and Korenaga, J. 2007. Journal of Geophysical Research 112, B03211, 1-21.

Lock, N.P. 1980.The geology of the Letseng kimberlites, Lesotho. Ph.D. thesis, University of Sheffield.

Lock, N.P. and Dawson, J.B. 1980. Transactions of the Royal Society of Edinburgh: Earth Sciences, 71, 47-53.

Nickel, K.G. and Green, D.H. 1985. Earth and Planetary Science Letters 73, 158-170.

Nimis, P and Grütter, H. 2010.. Contributions to Mineralogy and Petrology 159, 411-427.

Reid, A.M. and Dawson, J.B. 1972. Lithos, 5, 115124.

Rudnick, R.L. and Nyblade, A.A. 1999 In: Yingwei Fe, Berika,.C.M and Mysen, B.O. (eds) Mantle petrology: field observations and high pressure experimentation: a tribute to Francis R. (Joe) Boyd. Houston, Geochemical Society, Special Publication 6, 3-12

Simon, N.S.C, et al.. 2003.. Lithos 71, 289-322.

Taylor, W.R. 1998. Neues Jahrbuch für Mineralogie Abhandlungen 172, 381-408. 